Review Article

\title{
Design and Operation of Effective Landfills with Minimal Effects on the Environment and Human Health
}

\author{
Gulnihal Ozbay (D, Morgan Jones, Mohana Gadde, Shehu Isah, and Tahera Attarwala \\ Department of Agriculture and Natural Resources, Delaware State University, Dover, DE 19901, USA \\ Correspondence should be addressed to Gulnihal Ozbay; gulniozbay@yahoo.com
}

Received 15 July 2020; Accepted 10 August 2021; Published 7 September 2021

Academic Editor: John Yabe

Copyright (c) 2021 Gulnihal Ozbay et al. This is an open access article distributed under the Creative Commons Attribution License, which permits unrestricted use, distribution, and reproduction in any medium, provided the original work is properly cited.

\begin{abstract}
Totaling at 7.4 billion people, the world's population is rapidly growing, bringing along with it an increase in waste generation. The impact of this exponential increase in waste generation has resulted in the increased formation and utilization of landfills. In the present day, landfills are utilized to dispose of chemical, hazardous, municipal, and electronic wastes. However, despite their convenience, most landfills are improperly managed and face constant changes from the surrounding environment that interfere with their internal landfill processes. The objectives of this mixed review are to highlight the negative impacts landfills have on the environment and public health as well as outline the need for proper management practices to mitigate these effects. Inadequate management of landfills leads to issues concerning leachate collection and landfill gas (LFG) generation, which give rise to groundwater contamination and air pollution. This paper recognizes the disadvantages of utilizing landfills as the main disposal method by focusing on these two primary effects that improper management of landfills has on the environment and human health. Many experts have also reported that communities within close proximity to improperly managed landfills have an increased risk of health issues. Apart from implementing proper landfill management practices, it is important to develop solutions to reduce waste generation altogether. This review discusses some of the innovative methods implemented by other countries to reduce landfill waste and the production of greenhouse gases as well as possible steps individuals can take to minimize their ecological footprints.
\end{abstract}

\section{Introduction}

Waste management is a global issue, especially with the increased accumulation of solid waste every year [1]. In the 1990s, developed countries produced up to $800 \mathrm{~kg}$ of waste per capita, while developing countries produced a maximum of $200 \mathrm{~kg}$ per capita [2]. In 2010, the global solid waste production was estimated to be two billion tons [3]. Developed countries (the US, Canada, Japan, Australia, New Zealand, and Western Europe) accounted for half of this estimate. However, this estimate will reportedly change with urban population growth in developing countries. Further estimations show that by 2035, Asian and African countries will produce twice as much solid waste, while developed countries will produce less waste [3]. Nonetheless, current and future waste productions require effective landfill use, which varies globally. A landfill is defined as a well-engineered depression in the ground used for the disposal of solid waste. Landfills contain a variety of wastes, mainly consisting of municipal solid waste (MSW) or everyday single-use items such as packaging, grass clippings, furniture, clothing, bottles, food scraps, newspapers, appliances, paint, and batteries [4].

Municipal solid waste management differs throughout the world. For instance, zero percent of MSW in Sweden ends up in landfills, while in Bulgaria, almost 100 percent of their MSW ends up in landfills. In 2014, Europe overall sent $41 \%$ of collected MSW to landfills [1]. Unlike Europe, many Asian countries have other means of waste disposal such as open dumping and burning; therefore, any waste placed in landfills is done through unsanitary and unregulated methods. In the United States, over 50 percent of waste was 
landfilled in 2015 [1]. Although there are multiple means of waste disposal around the world, the use of landfills is one of the most common methods. This review will focus on landfill management in the US, with the majority of the data representing US waste generation.

According to the United States Environmental Protection Agency [4], every year the United States generates at least 254 million tons of waste. This translates to about two $\mathrm{kg}$ of waste generated per person, each day. Treatment of municipal solid waste in the United States (US) includes landfills $(52.1 \%)$, recycling (25\%), incineration or combusting with energy recovery (12.7\%), and composting (10.1\%) [4].

Relative proportions of these treatment methods from 1960 to 2017 are shown in Figure 6. According to the data, landfills are a more convenient waste disposal method, representing over $52 \%$ of waste disposed of in the US as of 2017. Our dependency on landfills has only continued to increase over the years due to an increase in population size. In 2000, the United States' population was 281.4 million, 308.7 million in 2010, and 323.1 million in 2016 [5]. With this population increase, the demand for manufactured products and materials grows, increasing waste generation as shown in Figure 7.

Consequently, different types of landfills exist in the US, each requiring different handling techniques and regulations for specific waste types. There are three main landfill types: industrial landfills, municipal solid waste landfills, and hazardous waste landfills. Industrial landfills process nonhazardous waste produced by industrial activities; municipal solid waste landfills (MSWLFs) mainly collect household and other general solid waste; and hazardous waste landfills process hazardous or toxic waste and are the most regulated and structured landfills. Each of these landfills have developed systems to manage the waste, which comprises liners, leachate collection, gas collection, drainage systems, runoff control, etc. There are also additional categories of landfills described in Section 2. Most wastes generated from our hospitals, schools, homes, and businesses are put into municipal solid waste landfills. Municipal solid waste landfills can also receive nonhazardous sludge, industrial solid waste, and construction debris, which can contribute to groundwater pollution, air pollution, and habitat destruction [4]. Many of these waste materials are nonbiodegradable and can sit in landfills for years without decomposing [4]. Landfills need to be continuously managed over long periods. Landfills are engineered so that they are located, designed, operated, and monitored to ensure compliance with federal regulations [4]. According to the Environmental Defense Fund [6], there are currently over 3,000 landfills in the United States.

Although landfills have satisfied the need for immediate waste disposal, this method is not ideal for long-term waste management and has multiple negative effects on the environment and public health. There are solid waste landfills that are well managed and designed as part of the integrated waste management system and protect the environment from contaminants that may be present in the solid waste stream; however, that is not always the case. Most landfills still contribute to many environmental issues including groundwater contamination from leachate generation and emission of greenhouse gases from landfill gas (LFG) generation [7]. Landfills can also render surrounding soil and land unusable. With the population increase and the inevitable growth in waste production, efforts toward proper waste management and waste reduction in the United States must be made to prevent further environmental damage [8].

The objectives of this mixed review are to (i) highlight the negative impacts landfills have on the environment and public health, (ii) outline the need for proper management practices to mitigate these effects, and (iii) evaluate possible solutions to manage waste generation, through the use of past case studies and research conducted on this topic and data provided by the Environmental Protection Agency. Bias is handled in this review by including multiple credible sources that support the claim that landfills have negative impacts on the environment and public health and by including both statistical data and photo evidence that further demonstrate this issue. This review will bridge the research gap from previous studies by comparing the practice and effectiveness of multiple landfill types as well as evaluating innovative methods to reduce landfill waste.

\section{Design and Regulations of Landfills}

In the US, all municipal solid waste landfills, industrial landfills, and hazardous landfills are expected to meet minimum national criteria under the "Resource Conservation and Recovery Act (RCRA)" to ensure the protection of human health and the environment [9]. An industrial waste landfill for disposal of nonhazardous industrial waste or commercial solid waste is regulated by RCRA subtitle D wastes. Specific regulations for handling various types of hazardous wastes are contained under subtitle C of RCRA in title 40 of the code of federal regulations (CFR): part 264 for permitted facilities and part 265 for interim status facilities [9]. These standards, in general, apply to owners and operators of landfill facilities across the United States of America.

There are multiple different landfill designs, each with their own separate processes and characteristics. Each landfill design has varying degrees of sustainability. These landfills include open dump landfills, controlled landfills, engineered landfills, and sustainable landfills.

2.1. Open Dump Landfills. Open dumping is a common practice in many developing countries around the world and is defined as a method of disposal of solid wastes indiscriminately without planning or control mechanisms. About $70 \%$ of countries around the world use "open dumping" as a method of disposal of municipal solid waste. Since these open dumpsites are not regulated, they are susceptible to open burning, scavengers, disease vectors, and elements [10]. The characteristics of these open dumpsites include lack of planning and control of dumpsites, inadequate or lack of regulation of types of wastes entering the site, waterlogging and leaching resulting in water pollution, open defecation by 
the public, lack of confinement of waste body, and uncontrolled burning of waste materials leading to air pollution. Open dump landfills are prohibited in the US [11]. A typical open dumpsite is shown in Figure 1.

These open dumpsites have no proper engineering design and therefore have no groundwater protection or drainage controls. Environmental risks posed by these open dump landfills need to be investigated to determine remedial actions on whether to close or upgrade the open dump to a controlled landfill. Environmental impact assessments (EIAs) should include flaws in site location (floodplains or groundwater), depth of existing open dumpsite and degree of compaction, variability of wastes within the site, and potential for mining decomposed organic materials [12].

2.2. Controlled Landfills. Controlled landfills are one level above open dump landfills, as controlled landfills are subject to basic control mechanisms such as the presence of an authority figure on site, control of vehicular movement and access to landfill, and basic waste handling techniques to ensure control and consolidation of the total body of wastes. At these sites, there is an installation of preliminary drainage control measures and a lack of uncontrolled burning of waste, and scavenging and foraging animals are minimized.

Although controlled landfills are more regulated than open dump landfills, they are still not viable since they do not conform with the fundamental principles of waste compaction and covering. Typical operational procedures include limiting the working face area, installation of litter barrier, and provision of daily cover. Waste volume is subject to control, as well as drainage systems and water quality.

\subsection{Engineered Landfills. Engineered landfills are disposal} sites that are constructed through planning and adoption of engineering techniques that ensure control of waste and avoidance of surface water through the installation of welldesigned and well-constructed surface drainage. Other characteristics include excavation and spreading of soil materials to cover the body of wastes, compacting of wastes into smaller layers, removal of leachate from wastes into lagoons or similar structures, venting of landfill gas out of wastes, and most importantly planned isolation of landfills from surrounding geology. These modern landfills are based on the concept of isolating landfills from the environment for proper stabilization of wastes and rendering them innocuous through biological, chemical, and physical treatments. An engineered landfill is represented by the MidMichigan landfill design in Figure 2.

Engineered landfills are often referred to as sanitary landfills due to the high standard of waste disposal. Sanitary landfills require a protected bottom where trash is buried in layers and compressed as a compact solid to ensure the safety of accumulated waste and ease of decomposition. The design, construction, and development of these landfills require sufficient planning from inception to its after-use stage. Location siting, construction, and operational

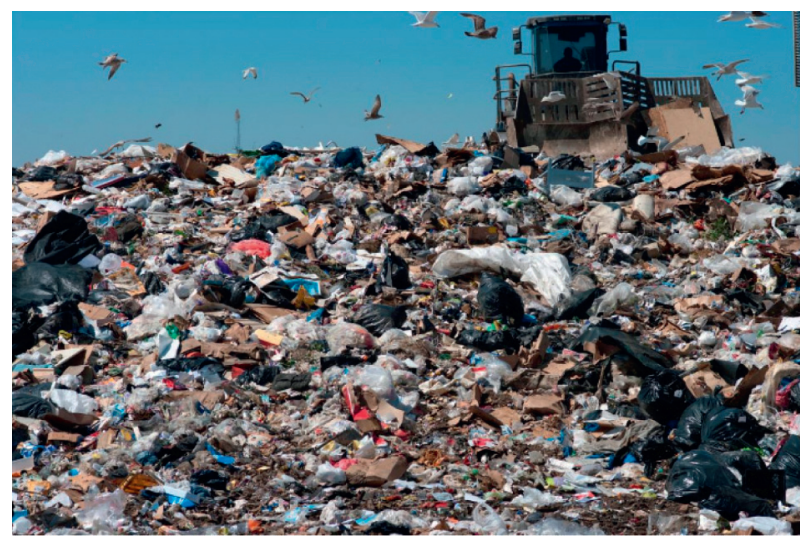

Figure 1: An open dump landfill (reprinted from HelpSave Nature, https://helpsavenature.com/).

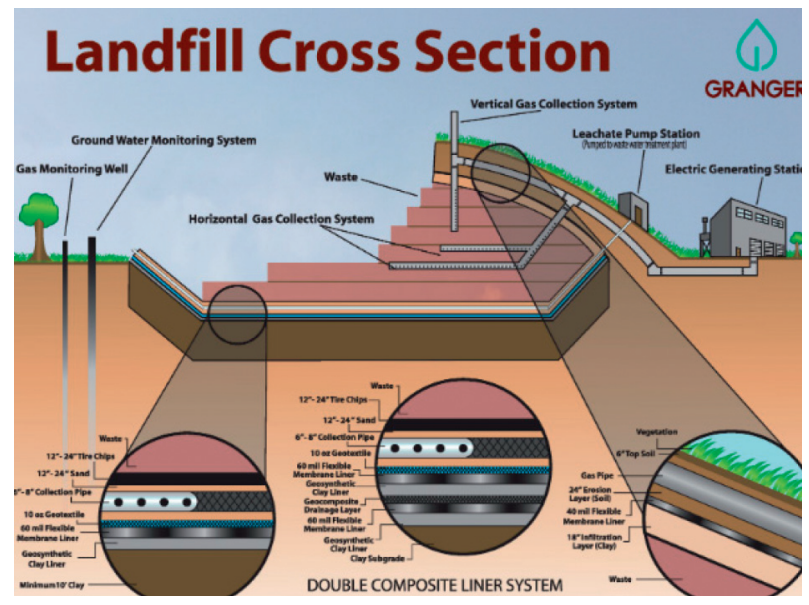

Figure 2: Mid-Michigan Engineered landfill design, https://www. grangernet.com./

requirements are much more stringent than other types of landfills. Thus, sanitary or engineered landfills are considered to have the least impact on public health and the environment [13].

2.4. Sustainable Landfills. The major driver of engineered or sanitary landfills has been the prevention of waste saturation to minimize the likelihood of leachate leaking into the surrounding ground. This approach has led to a very slow rate of waste degradation, with a projected stabilization period in the order of hundred years. However, degradation can be accelerated in principle by the controlled circulation of fluids through the waste and thus operating such engineered landfill as a bioreactor. This approach is more sustainable with regard to airspace, processes, control, and product utilization with minimal negative impacts on the environment and human health.

Sustainable landfills often have two different approaches with regard to parameters that control chemical and biological processes such as water content, temperature, microflora, and compaction rates. These led to anaerobic bioreactors and aerobic biocells $[14,15]$. Anaerobic 
bioreactors are similar in design to an engineered landfill with the following basic difference in their operational practice: a built-in leachate collection and recirculation system to enhance waste stabilization, geomembrane liners, a gas collection system, and final cover. Using this system, the methane gas that is predominantly produced can be collected, purified, and sold. Aerobic biocell systems utilize air circulation to maximize the rate of decomposition of waste. This latter system generates carbon dioxide as a preferred gas. A sustainable landfill utilizing an aerobic biocell design built by the Environmental Control System, Inc. (2001), in South Carolina is shown in Figure 3.

Stabilized waste in this system has limited methane gas and odor production, generates less harmful leachate capable of impacting groundwater, and ensures that the landfill recovers valuable airspace paving the way for a recycle (reusable) and sustainable landfill system.

\section{Environmental and Human Health Risks from Landfills}

A decision as to whether a landfill should be closed, rehabilitated, or remediated involves technical investigations and environmental impact assessments (EIAs). This requires a wide range of consultations with interested parties, especially the adjacent communities. A typical risk assessment process includes a set of logical, systemic, and well-defined activities that provide sound and unambiguous identification, measurement, quantification, and evaluation of the risks associated with landfills. Potential adverse effects to public health and the environment require evaluations of waterborne and airborne pollutants, assessment of the number of people affected by these pollutants, characteristics of wastes associated with the landfills, size of the landfill defined by the total amount of solid waste disposed of, and potential health conditions and psychological effects to public health.

Some simple quantification tools for risk assessments include hazard potential rating developed by Saxena and Bhardwaj [16] for an upgrade of existing municipal solid waste. Attributes are often grouped and weighed and therefore assigned weightage of attribute $\left(\mathrm{W}_{\mathrm{i}}\right)$ such that the total weight was 1000 . Each attribute is also measured in terms of sensitivity index ( $\mathrm{Si}$ ) on a scale of 0 to 1 to facilitate computation of cumulative scores called risk index (RI). Computed risk indexes are used to classify landfills for their environmental and public health impact. The RI is calculated according to

$$
\mathrm{RI}=\sum W_{i} S_{i},
$$

where $\mathrm{W}_{\mathrm{i}}$ is the weightage of the $\mathrm{i}$-th variable ranging from 0 to $1000 ; S_{i}$ is the sensitivity index of the $i$-th variable ranging from 0 to 1 ; and RI is the environmental risk index.

Landfills with high RI scores indicate a greater risk to human health and require immediate remedial measures. Landfills with low RI scores indicate low sensitivity and significant environmental impacts. Table 1 summarizes some of the tools that can be used for risk index assessments.

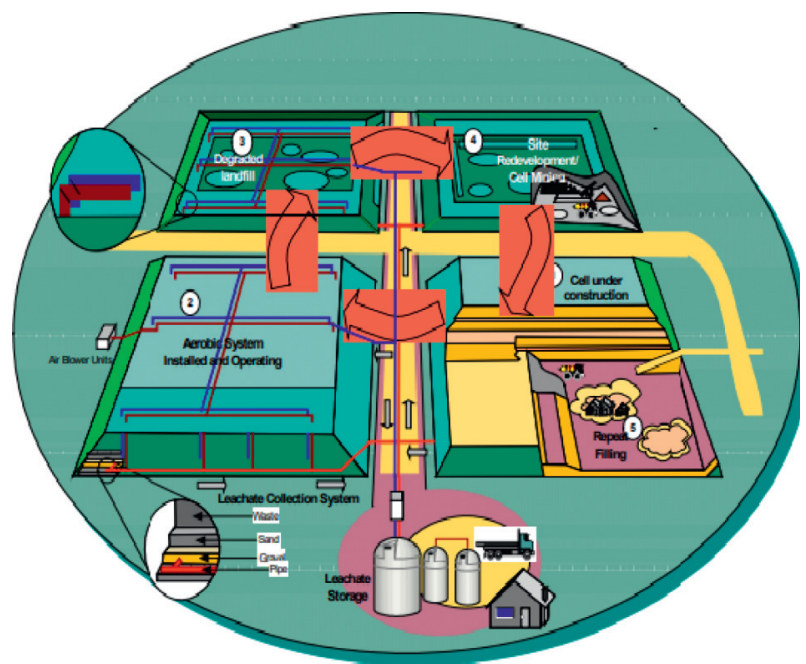

$$
\begin{array}{ll}
\text { Collected leachate } \\
\text { Injected Leachate } \\
\text { Injected Air }
\end{array}
$$

Figure 3: Aerobic biocell designed by the Environmental Control System, Inc., in South Carolina (2001).

\subsection{Environmental Impacts of Landfills}

3.1.1. Leachate Infiltration into Groundwater. Leachate is one of the three most common landfill problems, aside from toxins and greenhouse gases [8]. Leachate production and poor management techniques associated with uncontrolled landfills (especially open dump landfills) pose a significant threat to groundwater. Leachate is the contaminated liquid that drains from the waste material. Leachate is generated when rainwater filters through the waste, and the liquid is leached or drawn out. Chemicals and other constituents from the waste are potent in the leachate $[8,17]$. The contaminated liquid collects at the bottom of the landfill where it is typically withdrawn through a collection system. Leachate needs to be properly managed because it can percolate into and contaminate groundwater. One of the major targets of a landfill is to avoid any hydraulic or waterrelated connection between the waste and the surrounding environment because the primary environmental problem arising from landfills is groundwater contamination [17]. Several hazardous waste materials are deposited into landfills that can decompose, and if not properly managed (open dumping system), will end up in the groundwater (Figures 1 and 4). The toxic products in the landfills can range from industrial solvents to household cleaners. In a study conducted by the USGS on contaminants of emerging concerns (CECs) in landfill leachate, scientists used three analytical methods to determine CEC concentrations: a liquid chromatography-tandem mass spectrometry, a gas chromatography, and a GC/MS method. They found that "final leachate samples contained 101 of the 190 chemicals analyzed for the study, with chemicals present in every final leachate sample collected at levels ranging from as low as 2 nanograms per liter (ng/L) to as high as 17,200,000 ng/L” (2015, p.11). Quality-control samples were collected and analyzed to evaluate bias, accuracy, and precision of CEC concentrations 
TABLE 1: Some specific criteria for rapid risk assessment of landfills [16].

\begin{tabular}{|c|c|c|c|c|c|c|}
\hline \multirow{2}{*}{$\begin{array}{l}\text { SI. } \\
\text { no. }\end{array}$} & \multirow{2}{*}{ Attribute (site-specific criteria) } & \multirow{2}{*}{$\begin{array}{l}\text { Attribute } \\
\text { weightage }\end{array}$} & \multicolumn{4}{|c|}{ Sensitivity index } \\
\hline & & & $0.0-0.25$ & $0.25-0.5$ & $0.5-0.75$ & $0.75-1.0$ \\
\hline 1. & Distance from nearest water supply source (m) & 69 & $>5000$ & $2500-5000$ & $1000-2500$ & $<1000$ \\
\hline 2. & Depth of filling of waste $(\mathrm{m})$ & 64 & $<3$ & $3-10$ & $10-20$ & $>20$ \\
\hline 3. & Area of dumpsite (ha) & 61 & $<5$ & $5-10$ & $10-20$ & $>20$ \\
\hline 4. & Groundwater depth (m) & 54 & $>20$ & $10-20$ & $3-10$ & $<3$ \\
\hline 5. & Permeability of soil $\left(1 \times 10^{-6} \mathrm{~cm} / \mathrm{s}\right)$ & 54 & $<0.1$ & $1-0.1$ & $1-10$ & $>10$ \\
\hline 6. & Groundwater quality & 50 & $\begin{array}{l}\text { Not a } \\
\text { concern }\end{array}$ & Potable & $\begin{array}{l}\text { Potable if no } \\
\text { alternative }\end{array}$ & Nonpotable \\
\hline 7. & $\begin{array}{c}\text { Distance to critical habitats such as wetlands and } \\
\text { reserved forest }(\mathrm{km})\end{array}$ & 46 & $>25$ & $10-25$ & $5-10$ & $<5$ \\
\hline 8. & Distance to the nearest airport $(\mathrm{km})$ & 46 & $>20$ & $10-20$ & $5-10$ & $<5$ \\
\hline 9. & Distance from surface water body (m) & 41 & $>8000$ & $1500-8000$ & $500-1500$ & $<500$ \\
\hline 10. & Type of underlying soil (\% clay) & 41 & $>50$ & $30-50$ & $15-30$ & $0-15$ \\
\hline
\end{tabular}

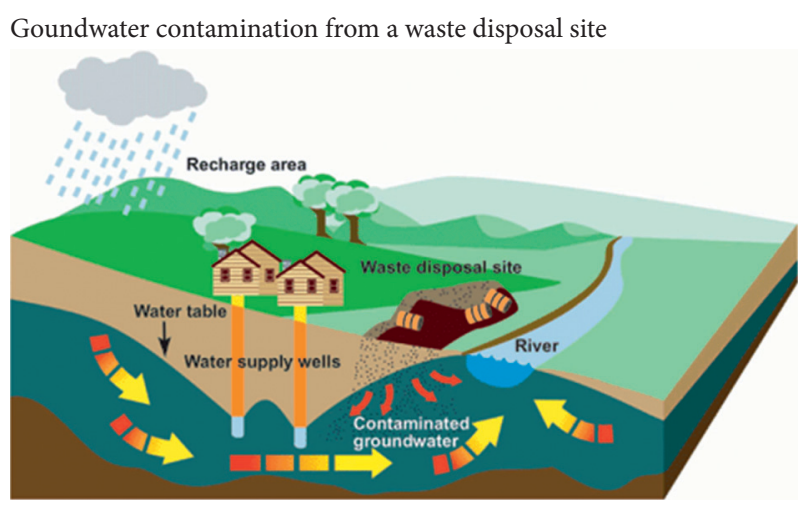

Figure 4: Potential contaminant sources from a waste disposal site (source: Walsh [18], National Academy of Sciences, Washington DC).

in leachate samples (2015, p.4). Lastly, a one-sided Wilcoxon rank sum test was used to test for any significant differences in the distribution of CEC concentrations between each sample group. The USGS scientists provided a list of all the chemicals found in the leachate [19] (Table 2).

Besides the chemicals from household and industrial products, there are also electronic wastes found in landfills that contain lead and mercury. A large percentage of these landfill toxins need to be properly managed in engineered landfills to avoid infiltration of these contaminants into the freshwater housed in underground aquifers. Eventually, the toxins may end up in domestic water and sometimes in the foods that we consume. The contamination can also harm animal and plant life [20]. Research conducted by the United States Environmental Protection Agency [4] reveals that $82 \%$ of landfills have leaks that require rehabilitation or remediation for a sustainable system (Figure 5). In a $\mathrm{Na}$ tional Geographic article titled Human Footprint, Kulpinski [20] states that an "increase in the risk of severe health and environmental implications has been reported in individuals living next to landfill areas in numerous studies." This calls for comprehensive EIAs to classify the risk index (RI) factor associated with most landfills. There are many public health concerns for people living close to uncontrolled landfills, a large proportion of those health concerns being associated with groundwater contamination from leachate [21]. Capping, the term used to describe covering a landfill, is one of the practices used by companies to prevent further toxic spills and leachate infiltration. While caps are not designed to remove or reduce contaminants, they do isolate and prevent the further spread of those contaminants. This is not an ideal method to eliminate or reduce contamination, but it is an effective short-term solution for containing those contaminants from polluting our lakes, streams, or groundwater [22].

The proper containment and storage of leachate is important, but eventually, the implementation of leachate treatment will be necessary for a long-term solution since the infrastructure holding the leachate can only withstand so long. There are various treatment options available to treat leachate (i.e., biological treatment via biofilters to remove nitrogen and other compounds and physical-chemical processes via oxidation, flocculation, adsorption, etc.); however, it is debatable how cost-effective those treatments are [8]. More research will need to be conducted to determine the most viable and cost-effective method for leachate treatment.

3.1.2. Landfill Gas Generation and Air Pollution. Another important detrimental effect of uncontrolled landfills on the environment is the generation of LFG. The primary LFG emissions are methane and carbon dioxide. However, gases such as hydrogen sulfide and mercury vapor can be emitted at low concentrations, while a mixture of volatile organic compounds (VOCs) comprises approximately $0.5 \%$ of gases emitted $[4,23]$. The extraction of LFGs is crucial because the gases are an explosive hazard. Furthermore, exposure to these gases can pose a threat to the surrounding population [4].

Companies can extract these gases since landfills are prime candidates for gas recovery and allows companies to execute gas-to-energy projects. This means that the gas generated by the landfill can be taken, converted, and then utilized to generate electricity in the form of heat or steam [21]. For landfill sites that do not have gas-to-energy projects, there are gas flare stations that are used to burn off 
TABLe 2: List of 101 chemicals found in leachate samples from 22 landfills in the US.

\begin{tabular}{|c|c|c|c|c|c|c|}
\hline Chemical $^{\mathrm{a}}$ & CASRN $^{\mathrm{b}}$ & $\begin{array}{c}\text { RL range } \\
(\mathrm{ng} / \mathrm{L})\end{array}$ & $\begin{array}{l}\text { Frequency } \\
(\mathrm{T})\end{array}$ & $\begin{array}{c}\text { Maximum } \\
(\mathrm{ng} / \mathrm{L})\end{array}$ & $\begin{array}{c}\text { Detection } \\
\text { median }^{c}(\mathrm{ng} / \mathrm{L})\end{array}$ & Primary chemical use \\
\hline Diazepam (1) & $439-14-5$ & $2-44$ & 5 & E 42.1 & E 42.1 & $\begin{array}{l}\text { Antianxiety, sleep aid, } \\
\text { anticonvulsant }\end{array}$ \\
\hline Diltiazem (1) & $\begin{array}{c}42399-41- \\
7\end{array}$ & $10-204$ & 5 & 12.0 & 12.0 & Calcium channel blocker \\
\hline Erythromycin (1) & $114-07-8$ & $53-1060$ & 5 & 204 & 204 & Antibiotic \\
\hline Fluconazole (1) & $\begin{array}{c}86386-73- \\
4\end{array}$ & $71-1420$ & 50 & 1520 & 180 & Triazole antifungal \\
\hline Glipizide (1) & $\begin{array}{l}29094-61- \\
9\end{array}$ & $35-692$ & 5 & 155 & 155 & Antidiabetic \\
\hline Glyburide (1) & $\begin{array}{l}10238-21- \\
8\end{array}$ & $4-79$ & 9 & 25.8 & 24.4 & Antidiabetic \\
\hline Loperamide (1) & $\begin{array}{c}53179-11- \\
6\end{array}$ & $11-230$ & 5 & 47.4 & 47.4 & Antidiarrheal \\
\hline Lorzepam (1) & $846-49-1$ & $116-1160$ & 5 & E 4820 & E 4820 & Antianxiety \\
\hline Meprobamate (1) & $57-53-4$ & $86-1720$ & 36 & E 1530 & 467 & Carbamate derivative, anxiolytic \\
\hline Metaxalone (1) & $1665-48-1$ & $15-312$ & 41 & 1710 & 303 & Muscle relaxant \\
\hline Metformin (1) & $657-24-9$ & $13-262$ & 41 & 838 & 395 & Antidiabetic \\
\hline Methadone (1) & $76-99-3$ & $7-152$ & 9 & 1932 & 981 & Synthetic opioid, analgesic \\
\hline Methocarbamol (1) & $532-03-6$ & $9-174$ & 36 & 1210 & 144 & Muscle relaxant \\
\hline Methotrexate (1) & $59-05-2$ & $52-1050$ & 9 & 315 & 254 & Antifolate \\
\hline Metoprolol (1) & $\begin{array}{c}51384-51- \\
1\end{array}$ & $28-550$ & 14 & E 461 & E 423 & Antihypertensive \\
\hline Nadolol (1) & $\begin{array}{l}42200-33- \\
9\end{array}$ & $81-1620$ & 9 & E 319 & 238 & Beta blocker \\
\hline Nizatidine (1) & $\begin{array}{c}76963-41- \\
2\end{array}$ & $19-380$ & 5 & 25.3 & 25.3 & Acid inhibitor \\
\hline Oseltamivir (1) & $\begin{array}{c}196618- \\
13-0\end{array}$ & $15-292$ & 9 & E 147 & E 83.3 & Antiviral \\
\hline Paroxetine (1) & $\begin{array}{l}61869-08- \\
7\end{array}$ & $21-412$ & 5 & E 73.3 & E 73.3 & Antidepressant \\
\hline Penciclovir (1) & $\begin{array}{l}39809-25- \\
1\end{array}$ & $40-400$ & 5 & E 2140 & E 2140 & Antiviral \\
\hline Pentoxifylline (1) & 6493-05-6 & $9-187$ & 23 & 2841 & 856 & $\begin{array}{l}\text { Circulation enhancer (peripheral } \\
\text { blood flow) }\end{array}$ \\
\hline Phendimetrazine (1) & $634-03-7$ & $31-622$ & 5 & E 1110 & E1110 & Appetite suppressant \\
\hline Phenytoin (1) & $57-41-0$ & $188-3760$ & 32 & 2410 & 274 & Antiepileptic \\
\hline Quinine (1) & $130-95-0$ & $79-1600$ & 5 & E 284 & E 284 & $\begin{array}{l}\text { Antimalarial, flavorant, mild } \\
\text { antipyretic and analgesic }\end{array}$ \\
\hline Sulfadimethoxine (1) & $122-11-2$ & $65-1310$ & 18 & E 401 & 183 & Antibiotic \\
\hline Sulfamethizole (1) & $144-82-1$ & $104-2080$ & 5 & 861 & 861 & Antibiotic \\
\hline Thiabendazole (1) & $148-79-8$ & $4-82$ & 55 & 1770 & 211 & Parasiticide, fungicide \\
\hline Tramadol (1) & $\begin{array}{l}27203-92- \\
5\end{array}$ & $15-302$ & 55 & 1490 & 279 & Opiate \\
\hline Triamterene (1) & $396-01-0$ & $5-105$ & 18 & 14.9 & 12.7 & Diuretic \\
\hline Valacyclovir (1) & $\begin{array}{l}124832- \\
26-4\end{array}$ & $163-3260$ & 5 & E 765 & E 765 & Antiviral \\
\hline Venlafaxine (1) & $\begin{array}{c}93413-69- \\
5\end{array}$ & $5-90$ & 5 & 168 & 168 & Antidepressant \\
\hline Warfarin (1) & 81-81-2 & $6-121$ & 36 & E 70 & 23.0 & Anticoagulant, rodenticide \\
\hline $\begin{array}{l}\text { Steroid hormones } \\
\text { cis-Androsterone (2) }\end{array}$ & $53-41-8$ & 0.8 & 23 & 125 & 72.3 & Natural androgen \\
\hline Equilenin (2) & $517-09-0$ & 1 & 5 & 18 & 18 & $\begin{array}{l}\text { Natural equine estrogen, } \\
\text { hormone replacement therapy }\end{array}$ \\
\hline Estriol (2) & $50-27-1$ & 2 & 9 & 6.50 & 5.01 & Natural estrogen \\
\hline Estrone (2) & $53-16-7$ & 0.8 & 23 & 145 & 18.1 & Estradiol degradate \\
\hline Norethindrone (2) & $68-22-4$ & 0.8 & 5 & 30.1 & 30.1 & Synthetic progestin \\
\hline Household chemicals & & & & & & \\
\hline Acetophenone (3) & $98-86-2$ & 4000 & 23 & E 63800 & 15800 & Fragrance and/or flavorant \\
\hline Benzophenone (3) & $119-61-9$ & $400-1600$ & 32 & E 7310 & 2690 & Fixative for perfumes and soaps \\
\hline
\end{tabular}


TABle 2: Continued.

\begin{tabular}{|c|c|c|c|c|c|c|}
\hline Chemical $^{\mathrm{a}}$ & CASRN $^{\mathrm{b}}$ & $\begin{array}{c}\text { RL range } \\
(\mathrm{ng} / \mathrm{L})\end{array}$ & $\begin{array}{l}\text { Frequency } \\
(\mathrm{T})\end{array}$ & $\begin{array}{l}\text { Maximum } \\
(\mathrm{ng} / \mathrm{L})\end{array}$ & $\begin{array}{c}\text { Detection } \\
\text { median }^{c}(\mathrm{ng} / \mathrm{L}) \\
\end{array}$ & Primary chemical use \\
\hline Bisphenol A (BPA) (2) & $80-05-7$ & 100 & 77 & E 17200000 & E 45400 & $\begin{array}{c}\text { Component of plastics and } \\
\text { thermal paper }\end{array}$ \\
\hline Camphor (3) & $72-22-2$ & 400 & 55 & E 342000 & 62400 & Fragrance and/or flavorant \\
\hline d-Limonene (3) & $5989-27-5$ & 1600 & 5 & E 3400 & E 3400 & Pesticide, fragrance in aerosols \\
\hline Galaxolide (3) & $1222-05-5$ & 200 & 14 & E 928 & 302 & Polycyclic musk fragrance \\
\hline Isoquinoline (3) & $119-65-3$ & 400 & 5 & 801 & 801 & Fragrance and/or flavorant \\
\hline Menthol (3) & $1490-04-6$ & 3200 & 18 & 82900 & 27800 & Flavorant \\
\hline $\begin{array}{l}\text { N, N-diethyltoluamide } \\
\text { (DEET) (3) }\end{array}$ & $134-62-3$ & 400 & 68 & E 431000 & 45500 & Insect repellent \\
\hline Skatol (3) & 83-34-1 & 400 & 23 & 31900 & 8200 & Fragrance \\
\hline $\begin{array}{l}\text { Tri(2-chloroethyl)phosphate } \\
\text { (3) }\end{array}$ & $115-96-8$ & 6400 & 27 & 9100 & 8100 & Plasticizer, flame retardant \\
\hline $\begin{array}{l}\text { Tri(dichlorisopropyl) } \\
\text { phosphate (3) }\end{array}$ & $\begin{array}{c}13674-87- \\
8\end{array}$ & 1600 & 9 & E 2390 & E 2070 & Flame retardant \\
\hline Tributylphosphate (3) & $126-73-8$ & 640 & 45 & 7770 & 2000 & $\begin{array}{l}\text { Antifoaming agent, flame } \\
\text { retardant }\end{array}$ \\
\hline \multicolumn{7}{|l|}{ Industrial chemicals } \\
\hline 1,4-Dichlorobenzene (3) & $106-46-7$ & 400 & 32 & 2830 & E 797 & $\begin{array}{l}\text { Moth repellent, fumigant, } \\
\text { deodorant }\end{array}$ \\
\hline 1-Methylnaphthalene (3) & $90-12-0$ & 400 & 18 & 2260 & 983 & Component of petroleum \\
\hline 2,6-Dimethylnaphthalene (3) & $581-42-0$ & 400 & 5 & 421 & 421 & Component of diesel/kerosene \\
\hline 2-Methylnaphthalene (3) & $91-57-6$ & 400 & 9 & 2840 & 1900 & Component of petroleum \\
\hline $\begin{array}{l}3,4, \text { Dichlorophenyl } \\
\text { isocyanate ( } 3 \text { ) }\end{array}$ & $102-36-3$ & 200 & 5 & E 1010 & E 1010 & Industrial chemical intermediate \\
\hline 4-Cumylphenol (3) & $599-64-4$ & 400 & 18 & E 12800 & E 10000 & Plasticizer, flame retardant \\
\hline 4-Nonylphenol (3) & $\begin{array}{l}84852-15- \\
3\end{array}$ & 200 & 32 & E 83200 & E 18500 & Nonionic detergent degradate \\
\hline $\begin{array}{l}\text { 4-Nonylphenol diethoxylate } \\
\text { (3) }\end{array}$ & $\begin{array}{c}26027-38- \\
2\end{array}$ & 2000 & 18 & E 146000 & 24500 & Nonionic detergent degradate \\
\hline 4-Tert-octylphenol (3) & $140-66-9$ & 400 & 55 & E 6870 & E 1860 & Nonionic detergent degradate \\
\hline $\begin{array}{l}\text { 4-Tert-octylphenol } \\
\text { diethoxylate (3) }\end{array}$ & $2315-61-9$ & 2000 & 5 & 47000 & 47000 & Nonionic detergent degradate \\
\hline $\begin{array}{l}\text { 4-Tert-octylphenol } \\
\text { monoethoxylate ( } 3 \text { ) }\end{array}$ & $2315-67-5$ & 2000 & 5 & 15300 & 15300 & Nonionic detergent degradate \\
\hline $\begin{array}{l}\text { 5-Methyl-1H-benzotriazole } \\
\text { (3) }\end{array}$ & $136-85-6$ & 3200 & 18 & E 6480 & E 5820 & $\begin{array}{c}\text { Antioxidant in antifreeze and } \\
\text { deicers }\end{array}$ \\
\hline Anthracene (3) & $120-12-7$ & 200 & 27 & 1570 & 631 & $\begin{array}{l}\text { Component of tar, diesel, or } \\
\text { crude oil }\end{array}$ \\
\hline Anthraquinone (3) & $84-65-1$ & 400 & 14 & E 691 & E 532 & $\begin{array}{c}\text { Dye/textiles, seed treatment, bird } \\
\text { repellent }\end{array}$ \\
\hline Diethyl phthalate (3) & $84-66-2$ & 2000 & 18 & E 14100 & 6500 & $\begin{array}{c}\text { Plasticizer for polymers and } \\
\text { resins }\end{array}$ \\
\hline Fluoranthene (3) & $206-44-0$ & 200 & 5 & E 430 & E 430 & $\begin{array}{c}\text { Component of coal tar and } \\
\text { asphalt }\end{array}$ \\
\hline Isopropylbenzene (3) & $98-82-8$ & 400 & 18 & 1110 & 964 & Fuels and paint thinner \\
\hline Methyl-1H-benzotriazole (1) & $\begin{array}{c}29385-43- \\
1\end{array}$ & $141-2820$ & 59 & E 9660 & 1310 & Corrosion inhibitor \\
\hline Naphthalene (3) & $91-20-3$ & 200 & 55 & 17300 & 598 & $\begin{array}{l}\text { Fumigant, component of } \\
\text { gasoline }\end{array}$ \\
\hline Para-cresol (3) & $106-44-5$ & 800 & 32 & 1580000 & 117000 & Wood preservative \\
\hline Phenanthrene (3) & $85-01-8$ & 200 & 23 & 3600 & 358 & $\begin{array}{l}\text { Explosives, component of tar and } \\
\text { diesel fuel }\end{array}$ \\
\hline Phenol (3) & $108-95-2$ & 1600 & 27 & E 1190000 & E 98500 & Disinfectant \\
\hline \multicolumn{7}{|c|}{ Nonprescription pharmaceuticals and degradates } \\
\hline Acetaminophen (1) & $103-90-2$ & $7-143$ & 41 & 42600 & 5300 & Analgesic, antipyretic \\
\hline Caffeine (1) & $58-08-2$ & $900-1810$ & 32 & 3360 & 1340 & Stimulant \\
\hline Cimetidine (1) & $\begin{array}{l}51481-61- \\
9\end{array}$ & $27-556$ & 18 & 1085 & 211 & $\begin{array}{c}\text { Histamine H2-receptor } \\
\text { antagonist }\end{array}$ \\
\hline Cotinine (1) & $486-56-6$ & $18-127$ & 86 & E 30400 & E 597 & Nicotine degradate \\
\hline
\end{tabular}


TABLE 2: Continued.

\begin{tabular}{|c|c|c|c|c|c|c|}
\hline Chemical $^{\mathrm{a}}$ & CASRN $^{\mathrm{b}}$ & $\begin{array}{c}\text { RL range } \\
(\mathrm{ng} / \mathrm{L})\end{array}$ & $\begin{array}{l}\text { Frequency } \\
(\mathrm{T})\end{array}$ & $\begin{array}{c}\text { Maximum } \\
(\mathrm{ng} / \mathrm{L})\end{array}$ & $\begin{array}{c}\text { Detection } \\
\text { median }^{c}(\mathrm{ng} / \mathrm{L}) \\
\end{array}$ & Primary chemical use \\
\hline Dextromethorphan (1) & $125-71-3$ & $8-64$ & 18 & 204 & 70.3 & Cough suppressant \\
\hline Diphenhydramine (1) & $147-24-0$ & $6-116$ & 9 & 24 & 15.7 & Antihistamine \\
\hline Fexofenadine (1) & $\begin{array}{c}83799-24- \\
0\end{array}$ & $20-398$ & 14 & E 252 & E 237 & $\begin{array}{c}\text { Antihistamine, terfenadine } \\
\text { degradate }\end{array}$ \\
\hline Lidocaine (1) & $137-58-6$ & $15-304$ & 91 & E 47900 & 5380 & Local anesthetic \\
\hline Loratadine (1) & $\begin{array}{l}79794-75- \\
5\end{array}$ & $7-139$ & 5 & E 202 & E 202 & Antihistamine \\
\hline Nicotine (1) & $54-11-5$ & 1160 & 23 & E 43800 & E 6080 & Alkaloid stimulant \\
\hline Piperonyl butoxide (1) & $51-03-6$ & $3-161$ & 23 & E 238 & 35.7 & Pesticide synergist \\
\hline Pseudoephedrine (1) & $90-82-4$ & $11-222$ & 45 & E 6200 & 2150 & $\begin{array}{l}\text { Appetite suppressant, } \\
\text { decongestant, stimulant }\end{array}$ \\
\hline \multicolumn{7}{|l|}{ Pesticides and degradates } \\
\hline Atrazine (1) & $1912-24-9$ & $19-388$ & 9 & 507 & 466 & Herbicide \\
\hline Carbaryl (3) & $63-25-2$ & 600 & 5 & E 2530 & E 2530 & Insecticide \\
\hline \multicolumn{7}{|l|}{ Plant and animal sterols } \\
\hline 3-Beta-coprostanol (3) & $360-68-9$ & 200 & 59 & 176000 & 7980 & Fecal indicator \\
\hline Beta-sitosterol (3) & $83-46-5$ & 24000 & 5 & 190000 & 190000 & Phytoestrogen \\
\hline Cholesterol (3) & $57-88-5$ & 200 & 73 & 32300 & 7300 & Plant and animal sterol \\
\hline Stigmastanol (3) & $\begin{array}{c}19466-47- \\
8\end{array}$ & 17000 & 9 & 164000 & 143000 & Phytosterol \\
\hline \multicolumn{7}{|c|}{ Prescription pharmaceuticals and degradates } \\
\hline 1-Hydroxy-amitriptyline (1) & $\begin{array}{l}64520-05- \\
4\end{array}$ & $8-166$ & 5 & 415 & 415 & Amitriptyline degradate \\
\hline Abacavir (1) & $\begin{array}{c}136470- \\
78-5\end{array}$ & $22-444$ & 5 & 38.1 & 38.1 & $\begin{array}{c}\text { Antiviral, reverse transcriptase } \\
\text { inhibitor }\end{array}$ \\
\hline Acyclovir (1) & $\begin{array}{c}59277- \\
8403\end{array}$ & $22-444$ & 27 & 2720 & 582 & $\begin{array}{c}\text { Antiviral, reverse transcriptase } \\
\text { inhibitor }\end{array}$ \\
\hline Albuterol (1) & $\begin{array}{l}18559-94- \\
9\end{array}$ & $6-121$ & 18 & 377 & 268 & Bronchodilator \\
\hline Amphetamine (1) & $300-62-9$ & $8-163$ & 45 & 11900 & 614 & Psychostimulant \\
\hline Antipyrine (1) & $60-80-0$ & $116-2320$ & 23 & E 1060 & 189 & Analgesic, antipyretic \\
\hline Atenolol (1) & $\begin{array}{c}29122-68- \\
7\end{array}$ & $13-266$ & 32 & 1042 & E 178 & Beta blocker \\
\hline Bupropion (1) & $\begin{array}{c}34841-39- \\
9\end{array}$ & $17-356$ & 5 & 38.8 & 38.8 & Antidepressant \\
\hline Carbamazepine (1) & $298-46-4$ & $4-83$ & 77 & E 810 & 165 & $\begin{array}{c}\text { Anticonvulsant and mood } \\
\text { stabilizer }\end{array}$ \\
\hline Carisoprodol (1) & $78-44-4$ & $13-250$ & 82 & E 3060 & 322 & Muscle relaxant \\
\hline Desvenlafaxine (1) & $\begin{array}{c}93413-62- \\
8\end{array}$ & $7-150$ & 7 & E 656 & 225 & Venlafaxine degradant \\
\hline
\end{tabular}

${ }^{a}$ Value in parentheses indicates method: $(1)=$ liquid chromatography-tandem mass spectrometry (LC-MS/MS) pharmaceuticals; $(2)=$ gas chromatographytandem mass spectrometry (GC-MS/MS) steroid hormones; (3) = gas chromatography/mass spectrometry (GC/MS) household/industrial chemicals. ${ }^{\mathrm{b}} \mathrm{Chemical}$ abstracting service report number. ${ }^{\mathrm{c}}$ Median of detected concentrations. $\mathrm{CEC}=$ contaminant of emerging concern; $\mathrm{E}=$ flagged due to concentration being less than the RL or greater than the highest point on calibration curve; $\mathrm{RL}=$ reporting limit; Maximum = maximum concentration. Note. Reprinted from Landfill Leachate as a Mirror of Today's Disposable Society: Pharmaceuticals and Other Contaminants of Emerging Concern in Final Leachate from Landfills in the Conterminous United States, by Masoner, J.R., Koplin, D.W., Furlong, E.T., Cozzarelli, I.M., and Gray, J.L. (2015b). Retrieved from https:// setac.onlinelibrary.wiley.com/doi/abs/10.1002/etc.3219 copyright 2015 by Environmental Toxicology and Chemistry.

the flammable gas that is released by pressure relief valves [24]. Although there are other toxic gases emitted from landfills, methane and carbon dioxide are the primary emissions, with methane being the most environmentally damaging [25]. Methane gas is naturally produced during the process of organic matter decay (food, wood, textiles, garden waste, etc.) from bioreactors. The United States Environmental Protection Agency [4] reported that the methane expelled during the decomposition of organic matter, if unmanaged within the landfill, has the potential of trapping solar radiation 20 times more effectively than carbon dioxide. The outcome from the release of these gases from the landfill is increased global temperatures. Aside from methane gas, other household and agricultural chemicals like bleach and ammonia can generate toxic gases that can greatly impact the air quality within the landfill vicinity [26]. Dust, particulate matter, and other nonchemical contaminants can also be expelled into the atmosphere, contributing to poor air quality. As stated above, methane is flammable and LFGs combined with a large amount of landfill waste can easily lead to a fire outbreak if not properly contained. Once fires are ignited, it can be 


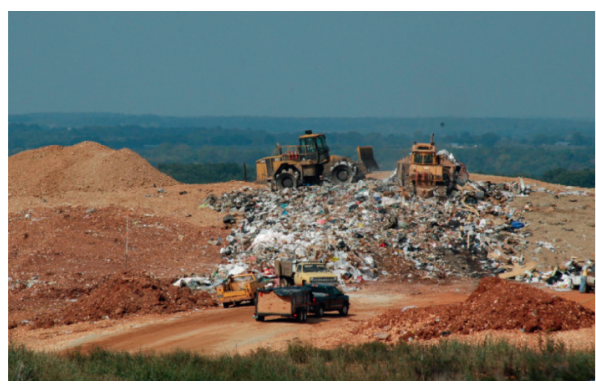

(a)

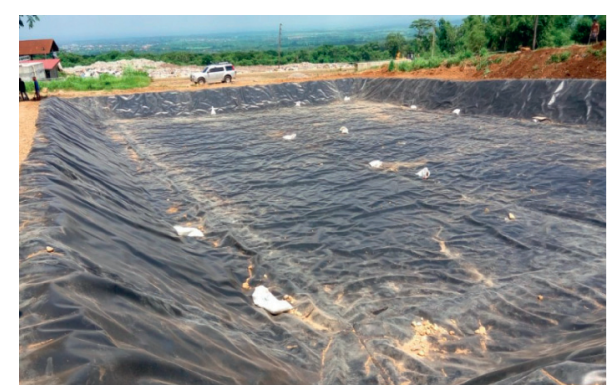

(b)

FIGURE 5: Sites undergoing rehabilitation for municipal solid waste landfill. (a) Reprinted from City of Springfield, https://www. springfieldmo.gov/2331/Solid-Waste-Management-Recycling-and-sanitary-landfill. (b) Reprinted from FABRIMETIRCS PHIL, INC., https:/fabphils.com/proj006-bataan-sanitary-landfill-phase-2.

challenging to extinguish them, resulting in further air pollution and destruction of neighboring habitats [27]. Combustion of the landfill worsens the situation, as the burning of the chemicals adds more chemical load into the area. The Environmental Defense Fund [6] states that methane is " 84 times more potent than carbon dioxide in the short term." LFG needs to be constantly monitored and extracted, as the production of toxic gases and odors can significantly impact air quality (United States Environmental Protection Agency (USEPA) [28]).

As part of their Landfill Methane Outreach Program, the USEPA [28] stated that "instead of escaping into the air, LFG can be captured, converted, and used as a renewable energy resource." By converting LFG, there is a reduction of odor and lower emissions of other hazards associated with LFG. This utilization prevents methane from migrating into the atmosphere, where it could contribute to local smog and global climate change. Besides a reduction in environmental pollution, using LFG as an energy source can also produce jobs and increase revenue [28]. The agency stated that generating power from the emitted methane is a clean, positive action taken by landfills and is a renewable solution (USEPA, 2018) [28]. Chen and Greene [29] of the Natural Resources Defense Council compiled a table of LFG EnergyUse projects (Table 3). Noticeably, LFG has many energy applications.

3.2. Human Health Implications. There have been multiple studies that show that residents living in the surrounding communities to uncontrolled landfills have negative health effects, some of which are related to groundwater contamination and air pollution. In a review article by Vrijheid [30] titled Health Effects of Residence Near Hazardous Waste Landfill Sites, multiple study sites situated near landfills that may or may not have already experienced environmental issues were observed. The findings were based on frequent concerns from the public of exposure to toxins (whether in the air or water) at a specific site and the health outcomes reported within the surrounding populations. Landfill sites may be a source of airborne chemical contamination through the migration of gases, particles, and chemicals that adhere to dust [30]. This article also states that "other
TABLE 3: Different uses for LFG energy.

\begin{tabular}{lcc}
\hline Landfill-gas energy use & $\begin{array}{c}\text { Number of } \\
\text { projects }\end{array}$ \\
\hline Electric & Reciprocating engines & 187 \\
& Gas turbines & 31 \\
& Other & 25 \\
Direct & All electric & 243 \\
& Boilers & 29 \\
& Direct thermal and leachate & 47 \\
& evaporation & 31 \\
Total & Other & 107 \\
All landfills & All direct & 350 \\
\hline
\end{tabular}

Note. Reprinted from Is Landfill Gas Green Energy?, by Chen and Greene [29]. Retrieved from https://www.nrdc.org/sites/default/files/lfg.pdf copyright 2003 by the Natural Resources Defense Council.

possible routes of exposure include direct contact through the contamination of soil, ground, and surface water or inhalation via pollution of indoor air in the case of evaporation of volatile organic compounds into basements of nearby houses" [30]. If the water used by residents becomes heavily contaminated, other water uses such as bathing may also lead to exposure to evaporated VOCs released from waste [31]. Areas surrounding uncontrolled landfills have increased incidences of health issues such as respiratory issues, skin irritations, gastrointestinal problems, fatigue, headaches, and psychological disorders [30]. Studies on landfill influence on public health are typically only conducted after officials have been notified about an odor being released from a landfill site or after residents have already begun to experience adverse health effects. These are selfreported cases, which show increased effects in populations exposed to waste sites compared with unexposed populations [32]. The review references a study done in Woburn, Massachusetts, where toxic chemicals from an uncontrolled waste disposal site were detected in municipal drinking water wells [33]. Residents of Woburn reported a cluster of leukemia cases in children. These reports were confirmed through hospital and pathology records, and a first study 


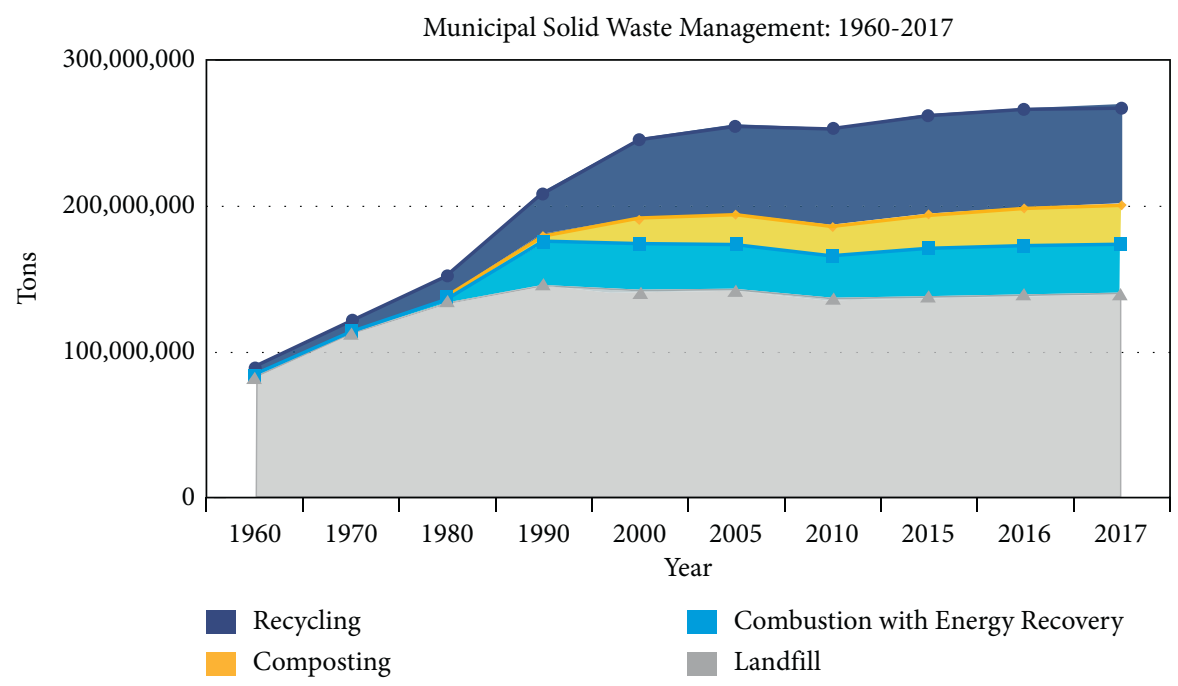

FIGURE 6: Composition of the US municipal solid waste management between 1960 and 2017 [9].

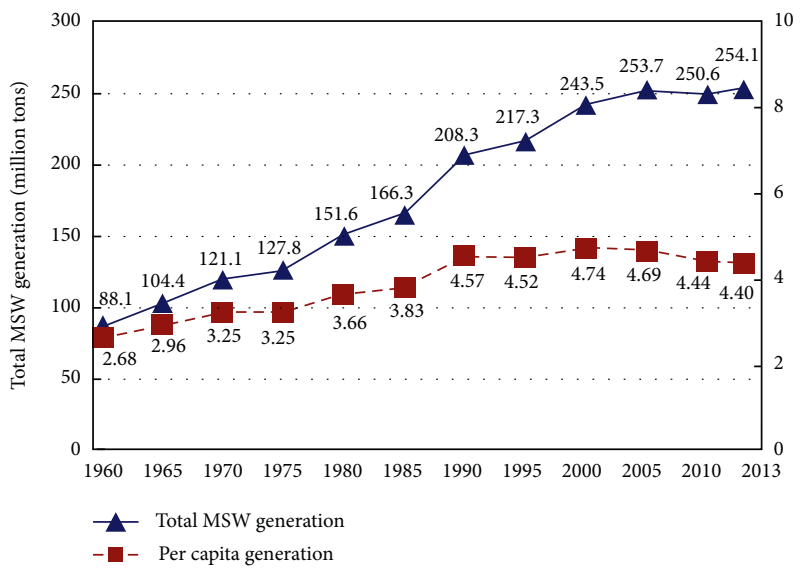

(a)

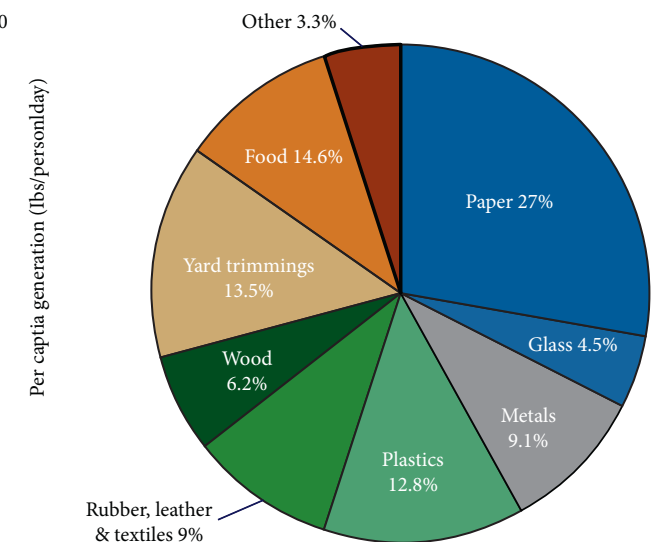

(b)

FigURE 7: 1960-2013 MSW generation (reprinted from EPA Archive, https://archive.epa.gov/epawaste/nonhaz/municipal/web/html/).

confirmed that this number was significantly higher than expected based on national rates [33]. The parents of the leukemia patients were later interviewed by selecting parents of two exact age and sex-matched well controls-one who lived close to the patient and the other who lived in the distal half of the city. Most of the East Woburn residents reported poor water quality, noting its bad odor, taste, color, and corrosiveness. Findings in these studies are consistent with conclusions made above: poor landfill management leads to air pollution and groundwater contamination, harming both the environment and people.

According to Rushton [21], "reproductive effects associated with landfill sites have been extensively researched and include low birth weight (less than $2500 \mathrm{~g}$ ), fetal and infant mortality, spontaneous abortion, and the occurrence of birth defects" (p.188). Furthermore, Rushton [21] and Griffith et al. [34] stated that through the use of National Priorities Listing (NPL) of hazardous waste sites developed by the US Environmental Protection Agency, there was an increased frequency of cancers in counties containing hazardous wastes that are not properly stored and disposed of in engineered landfills: particularly implicated are incidences related to gastrointestinal, esophageal, stomach, colon, and rectal cancers. On the other hand, Budnick et al. [35] studied the superfund site in Clinton County, Pennsylvania, and had found that the site was contaminated with the carcinogens $\beta$-naphthylamine, benzidine, and benzene. According to their study, they found an increased number of bladder cancer deaths among white males in Clinton County and a substantial increase in the number of other cancer deaths in the general population of Clinton and three surrounding counties during the 1970s [35]. However, no specific birth defects were significantly associated with the superfund site in this study.

\section{Innovative Methods Utilized at Landfills}

4.1. Reducing Landfill Waste. Though a majority of waste that ends up in landfills could potentially be minimized by implementing practices such as reducing, reusing, and 
recycling or completely getting rid of the plastic industry, it is just not feasible. Geyer et al. [36] wrote, "as of 2015, approximately $6300 \mathrm{Mt}$ of plastic waste had been generated, around $9 \%$ of which had been recycled, $12 \%$ was incinerated, and $79 \%$ was accumulated in landfills or the natural environment. If current production and waste management trends continue, roughly $12,000 \mathrm{Mt}$ of plastic waste will be in landfills or the natural environment by 2050". However, there are natural methods of waste disposal that can be utilized upon further investigation. One method is the usage of Galleria mellonella, commonly known as wax moth caterpillars. Polyethylene (PE) is a form of plastic that cannot biodegrade, as it is held together by C-C bonds [37]. In a study conducted by Bombelli et al. [37], the researchers placed a PE film next to the caterpillars and found destruction of the plastic within 40 minutes. The researchers reported that after placing 100 caterpillars in contact with a plastic bag for 12 hours, there was a $92 \mathrm{mg}$ reduction in the mass of the bag [37]. To account for the possibility that mechanical action was solely responsible for the $\mathrm{PE}$ breakdown, worm homogenates were smeared on and left in contact with the PE films. Gravimetric analysis of the treated samples confirmed significant mass loss of $13 \%$ PE over the span of 14 hours compared with the untreated samples [37]. The G. mellonella caterpillars achieved this by breaking down the chemical bonds that the PE consists of according to FTIR analysis. However, further research is necessary to determine whether the hydrocarbon-digesting activity of G. mellonella is derived from the organism or from enzymatic activities of its intestinal flora [37, 38]. Hopefully, further research and understanding of the G. mellonella caterpillars will one day be implemented on a larger scale to combat landfill waste.

4.2. Reducing Gas Emissions. Other approaches considered more sustainable with regard to airspace, processes, control, and product utilization with minimal negative effects on the environment and human health include integrating engineered landfills with anaerobic bioreactors or aerobic biocells. These systems will help reduce methane gas emissions by capturing, purifying, and redirecting the gas to be used toward energy projects.

As mentioned in an earlier section, methane is one of the primary greenhouse gases emitted from landfills. A journalist at the Technical University of Denmark, Jensen [39], writes that compared with carbon dioxide, methane is 25 times more detrimental. Thus, it is important to mitigate its effects. A common method utilized to reduce the release of methane is using soil to cover up landfill sites. However, not all gas is contained with this method [39]. In a pilot study conducted by Denmark researchers Schuetz et al. [40], a new biocover technology was utilized to achieve just this. This biocover technology functions by "sealing the surfaces of old landfills to prevent methane from penetrating them. Instead-by means of a gas drainage system-the gas is distributed through so-called 'biowindows,' which are most comparable to a compost bed. Here, the natural microorganisms of the compost transform methane into $\mathrm{CO}_{2}$
[39]."After implementing this technology at a Danish landfill site, they found that they were able to reduce methane production from $10 \mathrm{~kg} / \mathrm{hr}$ to just $1 \mathrm{~kg} / \mathrm{hr}$ [39]. This technology has proven effective in managing one greenhouse gas and has the potential to be utilized worldwide, greatly reducing methane emissions at landfill sites.

\section{Discussion}

Determining and assessing the risks posed by landfills is essential to relieving their direct effects on the environment. It is important to stress the issue of proper landfill management as a means of decreasing leachate and LFG contamination. Although landfills are environmentally straining, some actions can be taken to alleviate negative impacts. When a landfill reaches the end of its lifespan and can no longer collect any more waste, the waste management company will cap it [4]. Once closed, the landfill goes into the postclosure process where the company is responsible for managing that landfill for at least the next 30 years. Management is necessary as leachate and gas do not stop being produced. Once a landfill has been shut down, that land does not have many alternative uses [4]. However, companies are beginning to develop solar farms on top of landfills, which helps generate revenue. Furthermore, the multiple tax incentives provide more reason for companies to engage in the renewable energy industry.

Another important step that can be taken is to enforce federal regulation of landfills, which would ensure that the construction of landfills is well engineered and properly managed. Enforcement can significantly lessen the impacts a landfill has on the quality of soil, air, and water [4]. Landfills that are well designed and properly operated ensure compliance with environmental preservation requirements and ultimately ensure that the environment is contaminant-free [28]. Proper construction and maintenance also ensures that landfills are not located in environmentally sensitive areas and are incorporated with on-site environmental monitoring systems that track signs of gas release and groundwater contamination [28]. Landfill management will need to focus on designing and operating sustainable landfills. Similarly, communities also need to be a part of this sustainable future by focusing on decreasing their waste generation and thereby effectively limiting the negative effects of landfills [9].

\section{Conclusion}

According to the United States Environmental Protection Agency [4], the following steps can be taken to reduce our waste production and protect the environment: (1) respect the planet and all of its living and nonliving components, (2) rethink our consumption needs and avoid spending money on unnecessary things, (3) reduce wastage and waste accumulation, and (4) reuse and recycle products when possible. According to Annenberg Foundation [41], we can eventually reuse or recycle more than 70 percent of landfilled wastes, as the majority comprises valuable materials such as glass, metal, and paper. By reusing and recycling those 
materials, the demand for original natural sources of these materials can be reduced, and this can potentially eliminate severe environmental, economic, and public health issues. All in all, with our increasing population, waste generation will also increase, so it is crucial to recognize and mitigate the issues of leachate production and LFG generation to protect the environment and human health. Waste management companies need to enforce strict landfill regulations and people need to take it upon themselves to reduce their waste generation, which will reduce both the toxicity and volume of waste that ends up in landfills. However, in the time being, further studies need to be conducted to achieve greater insight into G. mellonella caterpillars and biocover technology, as both methods have proven effective and could be crucial in reducing the detrimental effects of landfills and landfill waste worldwide.

\section{Data Availability}

No data set was generated in this review article. References are provided for the data used in this review.

\section{Conflicts of Interest}

The authors declare that there are no conflicts of interest.

\section{Authors' Contributions}

Dr. Gulnihal Ozbay outlined and planned the review article, provided supervision and guidance to the coauthors, and contributed to writing, editing, and commenting on this review article. She helped both students extend the subject content and provided necessary revisions for article preparation. Morgan Jones reviewed the background contents and incorporated the first draft and discussion on the review. Mohana Gadde assisted with the review and added minimizing waste and greenhouse gases section. Dr. Shehu Isah and Tahera Attarwala provided further edits and comments and added sections to clarify the contents of the review article.

\section{Acknowledgments}

This review was funded by USDA NIFA Capacity Building Grant Programs (Award\# 2013-38821-21246 and Award\# 2016-06642) and the National Science Foundation EPSCoR Grant No. 1757353 and the State of Delaware.

\section{References}

[1] M. A. Karim and J. T. Wetterhan, "A comparative study of solid waste management in the United States, Europe and Asia," Annals of Civil and Environmental Engineering, vol. 4, pp. 003-011, 2020.

[2] M. D. Vaverkova, "Landfill impacts on the environmentreview," Geosciences, vol. 9, no. 10, pp. 2-16, 2019.

[3] D. C. Wilson and C. A. Velis, "Waste management-still a global challenge in the 21st century: an evidence-based call for action," Waste Management \& Research: The Journal for a Sustainable Circular Economy, vol. 33, no. 12, pp. 1049-1051, 2015.
[4] United States Environmental Protection Agency (USEPA), "Municipal solid waste," 2016, https://archive.epa.gov/ epawaste/nonhaz/municipal/web/html/.

[5] P. Mackun and S. Wilson, Population Distribution and Change: 2000 to 2010, U.S. Census Bureau, Suitland, SuitlandSilver Hill, MD, USA, 2011, https://www.census.gov/prod/ cen2010/briefs/c2010br-01.pdf.

[6] Environmental Defense Fund (EDF), Methane: The Other Important Greenhouse Gas, Environmental Defense Fund, New York, NY, USA, 2018, https://www.edf.org/methaneother-important-greenhouse-gas.

[7] Y. Jayawardhana, P. Kumarathilaka, I. Herath, and M. Vithanage, "Municipal solid waste biochar for prevention of pollution from landfill leachate," in Environmental Materials and Waste. Resources Recovery and Pollution Prevention, M. N. V. Prasad and K. Shih, Eds., Academic Press, Cambridge, MA, USA, pp. 117-148, 2016.

[8] B. Bausback, "The 3 most common landfill problems \& solutions," 2016, https://www.hcr-llc.com/blog/the-3-mostcommon-landfill-problems-solutions.

[9] United States Environmental Protection Agency CommunityFocused Exposure and Risk Screening Tool (USEPA C-FERST), "View your community," 2017, https://www.epa. gov/c-ferst.

[10] P. Rushbrook, Guidance on Minimum Approaches for Improvements to Existing Municipal Waste Dumpsites, Institutional Repository for Information Sharing. EUR/01/5021815, WHO Regional Office for Europe, Copenhagen, Denmark, 2001, https://apps.who.int/iris/handle/10665/108432.

[11] Federal facilities environmental stewardship and compliance center, https://www.fedcenter.gov/assistance/facilitytour/ solid/dumping/, 2017.

[12] HelpSave Nature, "Difference between sanitary landfills and open dumps you must know," February 2015, https:// helpsavenature.com/difference-between-sanitary-landfillsopen-dumps.

[13] K. Joseph, R. Nagengran, and K. Thanasekaran, Dumpsite Rehabilitation Manual, Center for Environmental Studies, Chennai, India, 2013.

[14] D. R. Reinhart and T. G. Townsend, Landfill Bioreactor Design and Engineering, CRC Press, New York, NY, USA, 1998.

[15] C. Zurbrugg, "The challenge of solid waste disposal in developing countries," SANDEC News, EAWAG, vol. 4, pp. 10-14, 1999.

[16] A. K. Saxena and K. D. Bhardwaj, "Environmental Assessment and up-gradation plan for existing municipal waste disposal site-a case study," in Proceeding of Workshop on Sustainable Landfill Management, pp. 287-301, Chennai, India, 2003.

[17] J. R. Masoner, D. W. Kolpin, and K. E. Lee, Landfill Leachate Released to Wastewater Treatment Plants and Other Environmental Pathways Contains a Mixture of Contaminants Including Pharmaceuticals, U.S. Department of the Interior | U.S. Geological Survey, Washington, DC, USA, 2015a, https://toxics.usgs. gov/highlights/2015-11-13-leachate_pathways.html.

[18] J. Walsh, Report: Cleanup of Some Contaminated Groundwater Sites in the U.S. Unlikely for Decades, http://www. constantinealexander.net/2012/11/report-cleanup-of-somecontaminated-groundwater-sites-in-the-us-unlikely-fordecades.html, National Academy of Sciences, Washington, DC, USA, 2012, http://www.constantinealexander.net/2012/ 11/report-cleanup-of-some-contaminated-groundwatersites-in-the-us-unlikely-for-decades.html.

[19] J. R. Masoner, D. W. Kolpin, E. T. Furlong, I. M. Cozzarelli, and J. L. Gray, "Landfill leachate as a mirror of today's 
disposable society: Pharmaceuticals and other contaminants of emerging concern in final leachate from landfills in the conterminous United States," Environmental Toxicology \& Chemistry, vol. 35, no. 4, pp. 906-918, 2015b.

[20] D. Kulpinski, Human Footprint. Human Footprint| National Geographic Channel, https://www.google.com/url?q=https:// groups.google.com/forum/\%23!topic/waitersworld-google/ AunIrh3Zk7A\&sa=D\&ust=1546039674972000\&usg=AFQj CNGz7q1Zsj5B3J8QWU1ayJArZh1Clg, 2018.

[21] L. Rushton, "Health hazards and waste management," British Medical Bulletin, vol. 68, no. 1, pp. 183-197, 2003.

[22] United States Environmental Protection Agency (USEPA), “A citizens guide to capping. Office of solid waste and emergency response (5102G). National service center for environmental publications EPA 542-F-12-004," 2012, https://www.epa.gov/ sites/production/files/2015-04/documents/a_citizens_guide_ to_capping.pdf.

[23] D. Zmirou, A. Deloraine, P. Saviuc, C. Tillier, A. Boucharlat, and N. Maury, "Short-term health effects of an industrial toxic waste landfill: a retrospective follow-up study in Montchanin, France," Archives of Environmental Health: An International Journal, vol. 49, no. 4, pp. 228-238, 1994.

[24] Republic Services, "Landfills. Responsible landfill management," 2018, http://www.republicservices.com/customersupport/facilities.

[25] Scottish Environmental Protection Agency (SEPA) Fact Sheet, "Scottish pollutant release inventory. Methane," 2018, http://apps.sepa.org.uk/spripa/Pages/SubstanceInformation. aspx?pid=65.

[26] Conserve Energy Future, "What are landfills?," 2018, https:// www.conserve-energy-future.com/causes-effects-solutions-oflandfills.php.

[27] J. Skye, "Environmental problems: landfills," 2014, https:// excesslogic.com/environmental-problems-landfills.

[28] United States Environmental Protection Agency (USEPA), "Basic information about landfill gas," 2018, https://www.epa. gov/lmop/basic-information-about-landfill-gas.

[29] C. Chen and N. Greene, Is Landfill Gas Green Energy?, Natural Resources Defense Council, New York, NY, USA, 2003, https://www.nrdc.org/sites/default/files/lfg.pdf.

[30] M. Vrijheid, "Health effects of residence near hazardous waste landfill sites: a review of epidemiologic literature," Environmental Health Perspectives, vol. 108, no. 2, pp. 101-112, 2000.

[31] C. S. Clark, C. R. Meyer, P. S. Gartside et al., "An environmental health survey of drinking water contamination by leachate from a pesticide waste dump in Hardeman County, Tennessee," Archives of Environmental Health: An International Journal, vol. 37, no. 1, pp. 9-18, 1982.

[32] J. N. Logue and J. M. Fox, "Residential health study of families living near the drake chemical superfund site in Lock Haven, Pennsylvania," Archives of Environmental Health: An International Journal, vol. 41, no. 4, pp. 222-228, 1986.

[33] J. J. Cutler, G. S. Parker, S. Rosen, B. Prenney, R. Healey, and G. G. Caldwell, "Childhood leukemia in Woburn, Massachusetts, USA," Public Health Reports 101:201-205, SAGE Publications Inc, Thousand Oaks, CA, USA, 1986.

[34] J. Griffith, R. C. Duncan, W. B. Riggan, and A. C. Pellom, "Cancer mortality in U.S. Counties with hazardous waste sites and ground water pollution," Archives of Environmental Health: An International Journal, vol. 44, no. 2, pp. 69-74, 1989.

[35] L. D. Budnick, J. N. Logue, D. C. Sokal, J. M. Fox, and H. Falk, "Cancer and birth defects near the drake superfund site,
Pennsylvania," Archives of environmental health, vol. 39, no. 5, pp. 409-413, 1984.

[36] R. Geyer, J. R. Jambeck, and K. L. Law, "Production, use, and fate of all plastics ever made," Science Advances, vol. 3, no. 7, Article ID e1700782, 2017.

[37] P. Bombelli, C. J. Howe, and F. Bertocchini, "Polyethylene bio-degradation by caterpillars of the wax moth Galleria mellonella," Current Biology, vol. 27, no. 8, pp. R292-R293, 2017.

[38] A. Dickman, "Studies on the waxmoth, Galleria mellonella, with particular reference to the digestion of wax by the larvae," Journal of Cellular and Comparative Physiology, vol. 3, no. 2, pp. 223-246, 1933.

[39] T. V. Jensen, "New technology reduces dangerous methane," 2015, https://www.dtu.dk/english/News/2015/07/Newtechnology-reduces-dangerous-methane $\mathrm{id}=7650 \mathrm{c} 52 \mathrm{~d}-103 \mathrm{f}-$ 45a5-b0b0-8db64a9ceb30.

[40] C. Schuetz, F. Cassini, J. D. Schoenmaeker, and P. Kjeldsen, "Mitigation of methane emissions in a pilot-scale biocover system at the AV Miljø Landfill, Denmark: 2. Methane oxidation," Waste Management, vol. 63, pp. 203-212, 2017, https:// www.sciencedirect.com/science/article/pii/S0956053X17300120? via\%3Dihub.

[41] Annenberg Foundation, Garbage: Solid Waste, Annenberg Foundation, 2016, http://www.learner.org/exhibits/garbage/ solidwaste.html. 